\title{
The principle of effectiveness: under strain?
}

Citation for published version (APA):

Eliantonio, M., \& Muir, E. (2019). The principle of effectiveness: under strain? Review of European

Administrative Law, 12(2), 255-265. https://doi.org/10.7590/187479819X15840066091268

Document status and date:

Published: 01/01/2019

DOI:

10.7590/187479819X15840066091268

Document Version:

Publisher's PDF, also known as Version of record

Document license:

Taverne

Please check the document version of this publication:

- A submitted manuscript is the version of the article upon submission and before peer-review. There can be important differences between the submitted version and the official published version of record.

People interested in the research are advised to contact the author for the final version of the publication, or visit the DOI to the publisher's website.

- The final author version and the galley proof are versions of the publication after peer review.

- The final published version features the final layout of the paper including the volume, issue and page numbers.

Link to publication

\footnotetext{
General rights rights.

- You may freely distribute the URL identifying the publication in the public portal. please follow below link for the End User Agreement:

www.umlib.nl/taverne-license

Take down policy

If you believe that this document breaches copyright please contact us at:

repository@maastrichtuniversity.nl

providing details and we will investigate your claim.
}

Copyright and moral rights for the publications made accessible in the public portal are retained by the authors and/or other copyright owners and it is a condition of accessing publications that users recognise and abide by the legal requirements associated with these

- Users may download and print one copy of any publication from the public portal for the purpose of private study or research.

- You may not further distribute the material or use it for any profit-making activity or commercial gain

If the publication is distributed under the terms of Article $25 \mathrm{fa}$ of the Dutch Copyright Act, indicated by the "Taverne" license above, 


\title{
The Principle of Effectiveness: under Strain?
}

\author{
Mariolina Eliantonio* \\ Professor of European and Comparative Administrative Law and Procedure, \\ Maastricht University \\ Elise Muir** \\ Head of the Institute for European Law, KU Leuven and Visiting Professor, College \\ of Europe
}

\section{Introduction}

This special issue sheds light on the evolving role of the principle of effectiveness in EU law in recent years and its relationship between the closely related principle of effective judicial protection, the right to an effective remedy under Article 47 of the Charter of Fundamental Rights (CFR), EU secondary procedural rules, and more recently the Member States' duty to ensure effective legal protection contained in Article 19 TEU.

The principle of effectiveness is very well established in EU law and dates back from the Rewe case, which enunciated that

'[A]pplying the principle of cooperation laid down in Article 5 of the [EEC] Treaty, it is the national courts which are entrusted with ensuring the legal protection which citizens derive from the direct effect of the provisions of Community law. Accordingly, in the absence of Community rules on this subject, it is for the domestic legal system of each Member State to designate the courts having jurisdiction and to determine the procedural conditions governing actions at law intended to ensure the protection of the rights which citizens have from the direct effect of Community law, it being understood that such conditions cannot be less favorable than those relating to similar actions of a domestic nature ... [I]n the absence of such measures of harmonization the right conferred by Community law must be exercised before the national courts in accordance with the conditions laid down by national rules. The position would be different only if the conditions and time-limits made it impossible in practice to exercise the rights which the national courts are obliged to protect. ${ }^{1}$

* DOI 10.7590/187479819X158400660912681874-7981 2019 Review of European Administrative Law

** This paper is part of a reflection on EU fundamental rights law supported by the European Research Council.

We are grateful to the Ius Commune Research School for hosting the workshop on which this special issue is based, as well as to SWOL and the KU Leuven Starting Grant scheme for financially contributing to the event.

1 Case 33-76 Rewe-Zentralfinanz e $G$ and Rewe-Zentral AG v Landwirtschaftskammer für das Saarland [1976] EU:C:1976:188, para. 5 . 
In the Johnston case, the Court of Justice of the European Union (the 'Court') introduced for the first time the principle of effective judicial protection, which was originally referred to as a principle which underlies the constitutional traditions common to the Member States and which is laid down in Articles 6 and 13 of the European Convention for the Protection of Human Rights and Fundamental Freedoms. ${ }^{2}$

The Court has not always treated the principles of effectiveness (Rewe, above) and effective judicial protection (Johnston, above) separately and as entailing different tests, ${ }^{3}$ and the difference between them has not been entirely straightforward, as pointed out by the doctrine. ${ }^{4}$ Further layers of complexity are created by the Court's references to other expressions such as the so-called 'effet utile' - used in the French language to refer to a broader interpretative principle but confusingly also referred to as 'effectiveness' in English;' and the notion of 'full effectiveness' of EU law, which has sometimes been used by the Court to enhance the intensity of the control on national procedural autonomy. ${ }^{6}$

This colourful (or blurry, depending on the personal chromatic taste) picture has been further complicated by the addition, through the Lisbon Treaty, of

2 Case 222/84 Marguerite Johnston v Chief Constable of the Royal Ulster Constabulary [1986] EU:C:1986:206.

3 See, for example, the statement in Impact, where it was held that the 'requirements of equivalence and effectiveness, [...] embody the general obligation on the Member States to ensure judicial protection of an individual's rights under Community law' (emphasis added). Case C-268/o6 Impact [2008] EU:C:2008:223, para. 47. Compare Impact with the statement of an almost contemporary case, Mono Car Styling: 'Thus, whilst it is, in principle, for national law to determine an individual's standing and legal interest in bringing proceedings, Community law nevertheless requires, in addition to observance of the principles of equivalence and effectiveness, that the national legislation does not undermine the right to effective judicial protection' (emphasis added). Case C-12/o8 Mono Car Styling SA, in liquidation v Dervis Odemis and Others [2009] EU:C:2009:466, para. 49.

4 S. Prechal and R. Widdershoven, 'Redefining the Relationship between "Rewe-effectiveness" and Effective Judicial Protection' (2011) 2 Review of European Administrative Law 31; A. Arnull, 'The Principle of Effective Judicial Protection in EU Law: An Unruly Horse?' (2011) 36 European Law Review 51; C. Lacchi, 'Multilevel judicial protection in the EU and preliminary references' (2016) 53 Common Market Law Review 679.

5 Olivier Dubos convincingly distinguishes between effet utile as an interpretative principle, and effectivité as a rule used to frame national procedural autonomy. See O. Dubos, 'L'effet utile et l'effectivité dans l'Union européenne: identification normative', in A. Bouveresse and D. Ritleng (eds), L'effectivité du droit de l'Union européenne (Bruylant 2018) 49.

6 The importance to preserve the 'full effectiveness' of EU law was for instance enunciated in Case C-213/89 Factortame [1990] EU:C:1990:257, para. 21; Case C-46/93 Brasserie du pêcheur [1996] EU:C:1996:79, paras 20, 39, 52 and 72; Case C-69/10 Samba Diouf[2011] EU:C:2011:524, para. 6o. See, for an overview of the case law relating to the principle of effectiveness and the requirement of full effectiveness of EU law, which might be qualified as 'enigmatic and even illogical': K. Havu, 'EU law in Member State courts: Adequate judicial protection and effective application - ambiguities and nonsequiturs in guidance by the Court of Justice' (2016) 8 Contemporary Readings in Law and Social Justice 158, 176. See further also J. Krommendijk, 'Is there light on the horizon? The distinction between "Rewe effectiveness" and the principle of effective judicial protection in Article 47 of the Charter after Orizzonte' (2016) 53 Common Market Law Review 1395, 1404. 
Article 47 of the Charter of Fundamental Rights, which enshrines the fundamental right to an effective remedy, and Article 19 TEU, on the basis of which Member States are required to ensure effective legal protection. ${ }^{7}$

The incremental creation of this complex layer of rights and principles which, to different extents, all serve to ensure that EU law is effectively enforced at national level and that individual rights stemming from EU law are effectively protected by national courts, deserves today a renewed attention, especially as a consequence of two sets of developments. First, because of the fact that the principle of effectiveness is increasingly often being used alongside other powerful constitutional principles, such as the fundamental right to an effective remedy enshrined in Article 47 of the Charter of Fundamental Rights. Secondly, because the principle of effectiveness co-exists with the multiplication of provisions of EU secondary legislation designed to equally support the effective implementation of EU law at domestic level.

In reaction to this twofold dynamic, this special issue asks: is the principle of effectiveness in the process of losing its constitutional relevance? It will be argued in this concluding article that, despite the challenges identified above, the concern for the effectiveness of EU law remains a powerful driving force behind the development of EU law, and that the principle of effectiveness still has a specific and autonomous added value in a number of settings. As emerges from the contributions to this special issue, although other constitutional concepts increasingly complement - or compete with - the principle of effectiveness, the latter has not lost its relevance (Section 2). It is only when detailed rules of secondary law exist that the principle is often left in the background (Section 3), although there too, the principle remains relevant. This article finishes with a set of broader reflections on the risks that may derive from the co-existence of legislative and constitutional versions of the same right in the increasingly dense legal landscape for the protection of fundamental rights (Section 4).

\section{Constitutional concepts co-existing with the principle of effectiveness}

The first set of pressures placed on the principle of effectiveness relates to the interplay between different sources at the level of EU primary law: the traditional case law of the Court of Justice of the European Union ('the Court') on the effectiveness of EU law, on the one hand; the new

$7 \quad$ S. Prechal and R. Widdershoven, 'Redefining the Relationship between "Rewe-effectiveness" and Effective Judicial Protection' (n 5); J. Engström, 'The Principle of Effective Judicial Protection after the Lisbon Treaty' (2011) 2 Review of European Administrative Law 53. 
wordings of Articles 47 CFR (and the related general principle of EU law) ${ }^{8}$ on the fundamental right to an effective remedy, as well as Article 19 TEU establishing the EU system of judicial remedies, on the other hand. These themes are explored in two of our contributions. How do the doctrines of effectiveness, the right to an effective remedy and the architecture of the system of judicial remedies interact? While Rob Widdershoven investigates the new relationship between the principle of effectiveness and the fundamental right to an effective remedy, Matteo Bonelli explores the impact of the new case law on Article 19 TEU on the architecture of the system of judicial remedies in the EU.

Rob Widdershoven focuses on the principle of effectiveness and its historical foundations on the one hand, and the fundamental right to an effective remedy enshrined in Article 47 CFR (equated with the corresponding general principle ${ }^{9}$ ) on the other hand. As noted by several of the contributions to this special issue - especially those by Mariolina Eliantonio on environmental policy and by Lilian Tsourdi on asylum policy - there is an increasingly prominent role of Article 47 of the Charter in the case law of the Court of Justice on national remedies. ${ }^{10}$ Did the Charter right to an effective remedy bury for good the principle of effectiveness?

Widdershoven points out that, in recent years, the Court has increasingly clearly distinguished between the right to an effective remedy and the principle of effectiveness in its assessment, giving priority to Article 47 CFR. ." This article of the Charter triggers varying degrees of scrutiny depending on the area of EU law at stake. However, overall, Widdershoven notes that the fundamental right to an effective remedy is given more bite than the Rewe principle of effectiveness, at times forcing the national courts to provide for access to a court and remedies not existing in national law. ${ }^{12}$ Widdershoven also notes that, despite multiple

8 For the purposes of the present contribution, we will treat the Johnston principle of effective judicial protection as equivalent in scope to the fundamental right to an effective remedy enshrined in Article 47 of the Charter. This proposed equivalence is warranted by the case law of the Court of Justice, which has, on several occasions, stated that Article 47 currently 'reaffirms' the general principle of effective judicial protection. See, amongst recent examples, Case C403/16 El Hassani [2017] EU:C:2017:960, para. 38; C-348/16 Sacko [2017] EU:C:2017:591, para. 31; Case C-73/16 Puškár [2017] EU:C:2017:725, para. 59; Case C-723/17 Craeynest and Others [2019] EU:C:2019:533. See also the contribution by Lilian Tsourdi in this special issue with specific reference to the asylum policy field. Ibid.

10 See also on this point P. van Cleynenbreugel, 'Case C-69/10, Brahim Samba Dioufv. Ministre $d u$ Travail, de l'Emploi et de l'Immigration, Judgment of the Court of Justice (Second Chamber) of 28 July 2011' (2011) 49 Common Market Law Review 327; P. van Cleynenbreugel, 'The confusing constitutional status of positive procedural obligations in EU law' (2012) 1 Review of European Administrative Law 81.

11 R. Widdershoven, Section 3.4.

12 R. Widdershoven, Section 3.3. 
overlaps, the principle of effectiveness may not always be subsumed in the right to an effective remedy. ${ }^{13}$

The principle of effectiveness retains a specific added value in a number of fields. Widdershoven identifies the rules on the ex officio application of EU law by the national courts as areas where the Rewe effectiveness will continue to retain relevance beyond Article $47 \mathrm{CFR}$. The same holds true for rules concerning the requirements under which final administrative decisions or final courts' judgments, being inconsistent with EU law, have to be reviewed. Widdershoven's finding on the continued relevance of the principle of effectiveness is in line with earlier research that interrogated itself on the demarcation between the principle of effectiveness and the right to an effective remedy. It was concluded that Rewe effectiveness - despite the concurring principle of effective judicial protection and even its coronation as a fundamental right through Article 47 CFR - is still very much alive and kicking. ${ }^{14}$

It may be recalled that the principle of effectiveness originates in the Member States' duty of loyal cooperation ${ }^{15}$; understood in that light, the principle of effectiveness may not always pursue the same objective as the individual's right to an effective remedy. We could illustrate this by reference to the tensions at stake in the Melloni ${ }^{16}$ ruling by the Court: the level of protection of the right of the defendant in criminal proceedings under domestic law hindered the ability of the national constitutional court to comply with its duty to ensure the effectiveness of the European Arrest Warrant. In the latter context, the driving forces behind the right to an effective remedy may even conflict with those behind the effectiveness of EU law, which are concerned with ensuring the success of a given EU policy. ${ }^{17}$ For a related example, limitations on the number of appeals against a return decision hinder the right to an effective remedy, although they may be deemed to contribute to furthering EU return policy. ${ }^{18}$

13 R. Widdershoven, Section 4.2.

14 J. Krommendijk, 'Is there light on the horizon? The distinction between "Rewe effectiveness" and the principle of effective judicial protection in Article 47 of the Charter after Orizzonte' (n 7); S. Prechal and R. Widdershoven, 'Redefining the Relationship between "Rewe-effectiveness” and Effective Judicial Protection' (n 5). Safjan and Düsterhaus distinguished four scenarios in the relationship between 'Rewe effectiveness' and the principle of effective judicial protection, i.e. 'super-position, coexistence, infusion and exclusivity'. M. Safjan and D. Düsterhaus, 'A Union of Effective Judicial Protection: Addressing a Multi-level Challenge through the Lens of Article 47 CFREU' (2014) 33 Yearbook of European Law 3, 12.

15 See Case 33/76 Rewe, para. 5- the first sentence of the second recital of para. 5 and related quote.

16 Case C-399/11 Stefano Melloni v Ministerio Fiscal [2013] EU:C:2013:107.

17 See further L. Azoulai, 'L'effectivité du droit de l'Union et les droits fondamentaux', in A. Bouveresse and D. Ritleng (eds), L'effectivité du droit de l'Union européenne (Bruylant 2018) 234236.

18 See, for instance, European Commission, 'Proposal for a Directive of the European Parliament and of the Council on common standards and procedures in Member States for returning illegally staying third-country nationals (recast)' [2018] COM/2018/634 final. Article 16(1) read in light of Recital (17) explains that the 'appeal against a return decision that is based on a decision rejecting an application for international protection which was already subject to an ef- 
The paper by Matteo Bonelli, in turn, examines the principle of effectiveness and the right to an effective remedy through a distinct constitutional lens. The important point made by his article is that this principle and this right have in recent months also been used to refine the architecture of the system for the protection of judicial remedies. His argument is that the recent case law of the CJEU on Article 19, inserted in the TEU by the Lisbon Treaty, adds a new and "truly groundbreaking' ${ }^{19}$ dimension to the debate on effective judicial protection in the EU.

In Bonelli's view, the Court's approach based on Article 19 TEU allows it to scrutinize a new range of domestic procedural rules that are understood to be of 'structural' or 'constitutional' importance. Article 19 TEU, as it is articulated in the ruling on Associação Sindical dos Juizes Portugueses ${ }^{2 \circ}$, allows the Court to interpret 'the fields covered by Union law' as being broader than the 'ordinary' scope of Union law, as well as the scope of application of the Charter, extending the reach of EU law to the structuring and functioning of the national judicial systems. ${ }^{21}$ On the other hand, the Court's reading of Article 19 TEU allows it to re-assert and possibly enhance its central position in the Union legal system of judicial remedies. ${ }^{22}$

Testimony to the uncertainty in the course taken by the Court of Justice in Associação Sindical dos Juizes Portugueses is the disagreement, expressed by some, on its role as a potential 'constitutional moment' ${ }^{23}$ in the process of European integration. Indeed, Serena Menzione in this special issue casts some doubts on the groundbreaking nature of this ruling: she sees it building on earlier case law and established principles. In particular, she argues that this case merely - albeit particularly strongly - restates the CJEU's role as guardian of the EU judicial system in a European Union based on the founding value of the rule of law, in line with earlier case law such as Les Verts. ${ }^{24}$

fective judicial remedy should take place before a single level of jurisdiction only'. See also E. Muir and C. Molinari, 'Targeted Impact Assessment of the Commission proposal for a Return Directive (recast) - legal aspects' (European Parliament, LIBE Committee, 2019) europarl.europa.eu/RegData/etudes/STUD/2019/631727/EPRS_STU(2019)631727_EN.pdf accessed 24 November 2019, 90 and, more generally, M. Safjan and D. Düsterhaus, 'A Union of Effective Judicial Protection: Addressing a Multi-level Challenge through the Lens of Article 47 CFREU' (n 15) 15-17.

Case C-64/16 Associação Sindical dos Juízes Portuguesesv Tribunal de Contas [2018] EU:C:2018:117.

M. Bonelli, Section 4.1.

M. Bonelli, Section 4.2.

23 A. von Bogdandy and others, 'Guest Editorial - A Potential Constitutional Moment for the European Rule of Law: The Importance of Red Lines' (2018) 55 Common Market Law Review $983,983$.

24 Case C-294/83 Les Verts v European Parliament [1986] EU:C:1986:166. 


\section{Legislative provisions competing with the principle of effectiveness}

The second set of pressures placed on the principle of effectiveness relates to the interplay between principles protected at the level of EU primary law, and EU secondary law containing rules of a procedural nature. As noted above, almost half a century ago, the Court decided on the Rewe case, ${ }^{25}$ setting the minimum requirements for national procedural rules when national courts are adjudicating on EU law cases. In a long line of subsequent case law, the Court refined its position with respect to national procedural rules and came to establish a system whereby the principles of equivalence and that of effectiveness apply 'in the absence of EU rules governing the matter'. ${ }^{26}$

While the principles of equivalence and effectiveness have been subject to much writing, the increasing legislative activity of the EU addressing the 'absence' of EU rules governing the matter has been subject to less scrutiny. The EU legislator has increasingly 'proceduralised' secondary EU law, adding ad hoc rules of a procedural nature in various instruments and very diverse policy areas, such as environmental, competition, asylum and public procurement law. $^{27}$ The rules thereby enshrined in EU legislation contribute to the effectiveness of the relevant instrument, and may enhance judicial protection and facilitate the implementation of the right to an effective remedy. Naturally, as usefully recalled by Rob Widdershoven in this special issue ${ }^{28}$, secondary legislation ought to comply with the fundamental right to an effective remedy enshrined in Article 47 of the Charter (and corresponding general principle of effective judicial protection). ${ }^{29}$ Furthermore, to the extent that the EU legislative institutions have laid down specific rules regarding procedural issues, there is no doubt that these rules prevail over national procedural law.

What other interactions may we observe between the principle of effectiveness, the right to an effective remedy, and related legislative provisions? This special issue seeks to address this question through the detailed examina-

25 Case 33/76 Rewe.

26 Case 33/76 Rewe, para. 5 .

27 See, for an overview of the phenomenon, M. Eliantonio and E. Muir, 'Concluding Thoughts: Legitimacy, Rationale and Extent of the Incidental Proceduralisation of EU Law' (2015) 1 Review of European Administrative Law 177.

28 R. Widdershoven, Section 2.4.

29 See $\mathrm{n} 10$ (above) on the Johnston principle of effective judicial protection being treated as equivalent in scope to the fundamental right to an effective remedy enshrined in Article 47 of the Charter. 
tion of the interplay between them in selected policy areas of EU law: criminal law, public procurement, migration and environmental policy. ${ }^{30}$

To start with, and importantly, the presence of EU legislation does not necessarily render the principle of effectiveness inapplicable. This is because, more often than not, secondary rules of a procedural nature set only minimum requirements, which are up to the Member States to flesh out in their implementation process. ${ }^{31}$ The policy-specific contributions by Roberto Caranta, Valsamis Mitsilegas, Mariolina Eliantonio and Lilian Tsourdi all confirm this conclusion. Legislation provisions such as those mandating Member States to ensure the existence of 'adequate and effective remedies', or 'not prohibitively expensive' procedures in the field of environmental law, as discussion by Eliantonio, are a clear example of this limited - or minimum - harmonisation.

Indeed, Eliantonio shows that the Court of Justice has concluded on several occasions that national procedural rules implementing European secondary law provisions of a procedural nature still need to comply with the principle of effectiveness and ensure the effectiveness of the underlying policy area. ${ }^{32}$ This conclusion resonates with the contribution by Tsourdi on asylum policy: she shows that the Court of Justice limited Member States' discretion in the implementation of secondary procedural rules by using the principle of effectiveness as well as Article 47 of the Charter, thereby contributing to enhance the functioning of the policy area.

The principle of effectiveness has not only served to limit the Member States' margin of manoeuvre in the implementation of secondary procedural rules, but has actually also sometimes contributed to boosting the strength of secondary procedural rules. This has been particularly striking in the criminal justice area. Mitsilegas indeed concludes that the effectiveness of EU-mandated defence rights has been strengthened by the CJEU's interpretation of EU secondary rules, because of the Court's understanding of effectiveness as including not only the effective enforcement of EU criminal law, but also - importantly - the effective exercise of EU fundamental rights enshrined in secondary law.

However, not all policy areas have witnessed this development. For example, Caranta concludes, with respect to the public procurement field, that the principles of effectiveness and the right to an effective remedy have - until recently, for certain - been quite peripheral in the Court's case law. That case law has been dominated by a simple assessment of national procedural rules against the benchmark of EU secondary rules. Quite opposite to Mitsilegas, he observes

\footnotetext{
30 See for instance, for complementary studies in other fields: J. Adams-Prassl, 'Article 47 CFR and the Effective Enforcement of EU Labour Law: Teeth for Paper Tigers?' (2020) European Labour Law Journal doi.org/10.1177/2031952520905383

31 This conclusion is shared by M. Safjan and D. Düsterhaus, 'A Union of Effective Judicial Protection: Addressing a Multi-level Challenge through the Lens of Article 47 CFREU' (n 15)10-11.

32 See also V. Mitsilegas, Section 5.
} 
that, in fact, reference to the principle of effectiveness and the right to an effective remedy in the CJEU's case law might end up undermining the level of protection of offered by the relevant secondary rules. This is because, according to Caranta, 'the Court of Justice has opted for a "peculiar collective understanding" of the right to effective judicial protection under Article 47 of the Charter focusing more on "issues of general design of the system" than on the effective protection of the economic operators' rights'. ${ }^{33}$ In this way, the secondary procedural rules, as interpreted by the Court against the tests of effectiveness (and Article 47), might end up reducing the scope for the judicial protection of economic operators.

\section{Spillover effects of the expansion EU constitutional principles in conjunction with EU legislation giving them flesh}

The last set of articles is at the junction between the two series of contributions introduced above. They look beyond the specificities of the principle of effectiveness and explore, in broader terms, the spillover effects of the expansion of case law on EU constitutional principles in conjunction with the development of EU legislation giving flesh to these same constitutional principles at domestic as well as EU level.

In her article, Chiara Favilli sheds light on the dangers associated with EU legislation providing for detailed procedural rules and setting a low level of protection of rights in the context of EU asylum law. As she powerfully argues, this may have a number of negative effects in domestic legal systems. Firstly, such EU legislation may be used by domestic political actors to support lowering the levels of judicial protection enshrined in national law - especially in politically sensitive fields, such as migration and asylum law, in the recent Italian context. ${ }^{34}$ Secondly, as a consequence of the Court's judgment in Melloni, it is now established that the existence of procedural rules enshrined in EU legislation may displace constitutional forms of protection that are deemed to constitute a threat to the 'primacy, unity and effectiveness of EU law'. ${ }^{35}$ Favilli stresses the severe impact that such an approach may have on the rights of asylum seekers, whose procedural rights are increasingly often enshrined in EU legislation. ${ }^{36}$

Thirdly, and most importantly, the author is not convinced that the interpretation of the fundamental right to an effective remedy ${ }^{37}$ by the Court of Justice

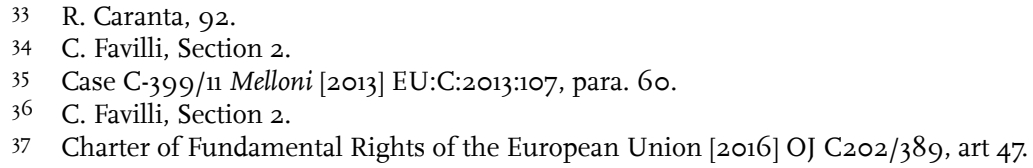


of the European Union, in the context of the implementation of related EU legislation ${ }^{38}$, always complies with the case law of the European Convention for Human Rights. To the contrary, she argues that the Court of Justice may have been negatively influenced by the restrictive tone of EU legislation, favoring the efficiency of EU migration and asylum policy over its protective function. ${ }^{39}$

Turning to a different set of fundamental rights - the fundamental rights to equal treatment and to annual paid leave - Elise Muir also calls for caution when fundamental rights are invoked alongside EU legislation protecting the same right. The co-existence of the two levels of norms for the protection of a given right enhances the visibility of the said right, and often allows enhancing the protection provided by a given EU right. Yet, it also creates a risk of confusion between the various layers of norms. The danger here is that one type of norm is used instead of the other, in disregard for the system of constitutional checks and balances that the authors of the Treaties have designed at the European level. ${ }^{40}$

More specifically, Muir argues against extending the recent case law on the horizontal direct effect of the Charter (in cases such as Egenberger, IR, Bauer, Max-Planck and Cresco $)^{41}$ beyond situations that are clearly regulated by EU rules other than the Charter per se. ${ }^{42}$ Otherwise, the Court may be accused of using the Charter to expand the competences of the European Union beyond the constitutional framework set out in the EU Treaties. This, to some extent, echoes the concern expressed by Matteo Bonelli in his contribution that the interplay between the various sources for the judicial protection of EU rights may create a feeling that the system for the allocation of competences in the EU is distorted.

\section{Conclusion}

After more than forty years from the first enunciation of the Rewe formula, the continued relevance of contributions such as those collected

38 In this context, Favilli examines Directive 2013/32/EU of the European Parliament and of the Council of 26 June 2013 on common procedures for granting and withdrawing international protection [2013] OJ L180/6o, art 46 - 'The right to an effective remedy'.

39

40 E. Muir, Section 3.2.

41 Case C-414/16 Vera Egenberger v Evangelisches Werk für Diakonie und Entwicklung e.V. [2018] EU:C:2018:257; Case C-68/17 IR v JQ [2018] EU:C:2018:696; Joined Cases C-569/16 and C570/16 Stadt Wuppertalv Maria Elisabeth Bauer and Volker Willmeroth v Martina Broßonn [2018] EU:C:2018:871; Case C-684/16 Max-Planck-Gesellschaft zur Förderung der Wissenschaften eVv Tetsuji Shimizu [2018] EU:C:2018:874; Case C-193/17 Cresco Investigation GmbHv Markus Achatzi [2019] EU:C:2019:43.

42 E. Muir, Section 3.3.2. 
in this special issue show that the vertical division of competences between the EU and the Member States in the field of remedies - as well as the interrelations between various tests and thresholds applicable to national procedural rules and defined alternatively by the EU legislature and judiciary - is far from being settled. A stunning amount of case law has been produced by the Court in response to national courts' questions on the compatibility of their own national procedural rules with the web of EU limitations.

This special issue has aimed at bringing further the reflection on how this web can be disentangled and how, in particular, the principle of effectiveness, the fundamental right to an effective remedy (as well as the related general principle of effective judicial protection), and the increasing amount of EU secondary rules of a procedural nature relate to each other. The contributions have shown, first of all, that, while being 'cornered' from many sides, the principle of effectiveness has not lost its relevance. It remains applicable even in the presence of EU secondary procedural rules, and it continues to remain one of the relevant tests to assess the compatibility of national procedural rules with EU law, in addition to the Charter right to an effective remedy.

The relation between the principle of effectiveness and the right to an effective remedy (as well as the corresponding general principle) continues to remain blurred, despite a clear trend towards an increasing prominence of the use of Article 47 CFR as 'main' test for national remedial rules in the case law of the Court. Similarly, the relationship between Article 47 CFR and Article 19 TEU certainly will call for further elaboration in the case law, which will need to determine the scope and 'power' of Article 19 TEU next to that of Article 47 CFR.

All in all, it seems clear that national procedural autonomy, if it ever existed, ${ }^{43}$ is slowly but surely being eroded by both the intensive control carried out by the Court (through the principle of effectiveness, Article 47 CFR and more recently Article 19 TEU) and by the increasingly amount of secondary legislation setting European standards for national procedural rules in many policy fields.

If it is, first and foremost, national courts who have to test national procedural rules against the applicable EU requirements, this complex layers of rules, rights and principles is making their task more and more challenging, and is at times threatening constitutional systems of checks and balances. One can therefore expect further preliminary references to the Court on the matter, and further academic work will be needed to map out the respective specificities of the different sets of norms explored in this special issue.

43 See for instance M. Bobek, "Why There is no Principle of "Procedural Autonomy" of the Member States', in H.-W. Micklitz and B. de Witte (eds), The European Court of Justice and the autonomy of the Member States (Intersentia 2012) 305-323. 